\title{
Market Orientation Conceptualizations, Components and Performance-Impacts: A Literature Review and Conceptual Framework
}

\author{
Caroline Osuagwu ${ }^{1}$ \\ ${ }^{1}$ School of Business and Entrepreneurship, American University of Nigeria, Nigeria \\ Correspondence: Caroline Osuagwu, School of Business and Entrepreneurship, American University of Nigeria, \\ Nigeria. E-mail: carolineosuagwu@gmail.com
}

Received: March 20, 2019 Accepted: April 15, $2019 \quad$ Online Published: May 21, 2019

doi:10.5539/ijms.v11n2p102 URL: https://doi.org/10.5539/ijms.v11n2p102

\begin{abstract}
Market orientation is the business idea that sees the customer, consumer or client as the centre of business activities. It is one of the strategies that may lead to the achievement of efficiency and effectiveness in many organizations. It has relevance for all sectors in an economy. This paper undertakes a review of market orientation literature pertaining to conceptualizations, components and performance impacts. Based on the literature review, the paper develops a conceptual framework and suggests likely areas for future research efforts.
\end{abstract}

Keywords: market orientation, narrative literature review, meta-analysis, conceptual framework

\section{Introduction}

Organizations use different types of management strategies to cope with business challenges in their business environment in order to achieve organizational performance. Market orientation is one of the major strategies used by companies to monitor, analyze and respond to business challenges in the environment in order to achieve organizational efficiency and effectiveness (Hooley, Greenley, Cadogan, \& Fahy, 2005). Generally, market orientation emphasizes customer satisfaction by coordinating functional marketing activities in order to achieve organizational efficiency and effectiveness (i.e., organizational performance). According to Lado et al. (1998), market orientation can be conceptualized as a competitive strategy that involves all functional areas and levels of an organization. Also, the role of market orientation as an organizational resource has been supported by various studies. Jabeen et al. (2013), for example, have argued that market orientation should be embraced by organizations for promoting lasting competitive advantage and greater firm performance, suggesting the need for further studies investigating the relationship between market orientation and performance in various forms of organizations.

Despite the positive outcomes of market orientation in developed countries, gaps have been observed in the study and implementation of market orientation in developing economies of Asia and Africa. In addition, it has been shown that the application of some Western management practices (such as market orientation) might not be successful in non-Western countries because of the mismatch between Western management practices and non-Western cultural values (Powpaka, 2006). Therefore, there are traces of equivocation regarding conceptualizations, components and performance-impacts of market orientation issues in extant literature. This paper presents a literature review of the conceptualizations, components and performance-impacts of market orientation issues in extant literature. In addition, the paper develops a conceptual framework to assist future research efforts.

\section{Literature Review in Scholarly Research}

Literature review presents the analytic and diagnostic views of scholars and writers with regard to areas of research interest. It is a critical review of relevant studies undertaken in specific areas of research interest, in addition to pulling different relevant strands of works together and locating any connections and contradictions among the works (Easterby-Smith et al., 2015). Generally, literature review is useful in scholarly studies because it helps in acquiring relevant and current knowledge in specific areas of research interest with respect to gaps in knowledge, strengths and weaknesses of research approaches used, development of hypotheses and conceptual 
frameworks, construct clarification, research instrument development, and discussion of implications of research results, among others. When the research issue of interest has many studies, it is very difficult to undertake a comprehensive literature review in such a situation (Sirelkhatim \& Gangi, 2015). Literature review can be written in many ways (Wee \& Bannister, 2016).

Narrative literature review has been the major task of many researchworks before the 1990s, and involved reading relevant research works on a research issue, summarizing results from such studies and arriving at reasonable conclusions and implications. Traces of subjectivity and lack of transparency, among others, are some of the limitations associated with narrative literature review, as opposed to systematic review and meta-analysis forms of literature review (Borenstein et al., 2011). In addition, systematic approach to literature review has the features of transparency, clarity, equality and accessibility, in addition to being unified and focused (Thorpe et al., 2006). Also, it helps to isolate known and unknown issues in specific area(s) of research interest (Bjjornseth \& Szabo, 2018). Consequently, some researchers have opted to use the systematic and meta-analysis forms of literature review instead of narrative literature review.

Systematic and meta-analysis methods of literature review have, however, been criticized to some extent. According to Matt and Cook (1994), threats to validity in narrative literature review are similar to those associated with systematic and meta-analysis methods of literature review. In addition, Franke (2001) argues that systematic and meta-analysis methods of literature review compare "apples and oranges" as these literature review methods do not focus completely on similar studies. Another argument against the use of systematic and meta-analysis methods of literature review is that both good and poor studies are included in the research samples, and the strengths from the good studies are likely to be contaminated by the weaknesses of the poor studies (Smith \& Glass, 1977). Also, it is argued that systematic and meta-analysis methods of literature review are associated with population bias (Franke, 2001).

These apparent limitations of the systematic and meta-analysis methods of literature review may encourage the use of narrative literature review methods in marketing studies. In addition, many researchers in marketing and cognate disciplines adopt narrative forms of literature review, as opposed to the systematic and meta-analysis methods, in their studies because of, perhaps, their limited skills and knowledge of the systematic and meta-analysis literature review methods. Generally, narrative literature review examines cognate research issues that would gain from a total clarification and integration of relevant literature on a research issue of interest (Toracco, 2005; Meij et al., 2017). According to Higgins and Smith (2016), narrative literature review provides a broad topic area of research interest and helps to have a wide understanding of the construct(s) of research interest (Nasheeda et al., 2018). It should be noted, however, that narrative, systematic and meta-analysis forms of literature review have their strengths and weaknesses in marketing research. Therefore, researchers should combine (triangulate) these literature review methods so that the weaknesses of some methods can be compensated by the strengths of the other methods.

\section{A Literature Review of Market Orientation Conceptualizations, Components and Performance-Impacts}

One major approach implicated in literature for achieving organizational performance in any business organization is through market orientation practices (Hooley et al., 2005; Day, Jaworski, \& Kohli, 1993; Narver \& Slater, 1990). Market orientation considers the customer/client as the centre of business activities and strategies (Deshpande \& Webster, 1994; Kumar et al., 2011; Hooley et al., 2005) argue that market orientation is the only widely-accepted and empirically-derived scale for measuring the marketing strategies of companies in all sectors of developed and developing economies. According to Carpenter (2017), the concept of market orientation, in the past, was elusive and lacked conceptual definition and clarification. In addition, relevant literature has criticized market orientation for its static and current-looking perspective of market resources (Helfat \& Peteraf, 2003; Priem \& Butler, 2001). However, over time, research on market orientation has increased appreciably thereby providing clarity, understanding and structure for conceptual and empirical studies (Deshpandé et al., 1989; Kohli \& Jaworski, 1990; Narver \& Slater, 1990, among others).

According to Tomaskova (2007), the major issues associated with the market orientation construct relate to definitions of the construct, dimensions of the construct, relationship between market orientation and performance measures, measurement methods for market orientation, and implementation of market orientation in companies. Therefore, this paper presents reviews of relevant literature relating to the following market orientation issues:

1) Conceptualizations of Market Orientation.

2) Components of Market Orientation. 


\section{3) Performance-Impacts of Market Orientation.}

\section{Conceptualizations of Market Orientation}

The marketing concept originated in the western developed countries following the industrial revolution. Over many decades, the marketing concept has passed through many orientations, including market orientation. The philosophy of the marketing concept posits that marketers should pay more attention to customers' needs and wants (Kohli \& Jaworski, 1990; Narver \& Slater, 1990, among others).

According to Kotler (1984), the marketing concept is a customer-oriented, integrated and profit oriented philosophy of business. It is a philosophy of business management based upon a company-wide acceptance of the need for customer orientation, profit orientation, and recognition of the important role of marketing in communicating the needs and wants of the market to all major corporate departments. Kotler (1998) argues that the key to achieving organizational goals depends on determining the needs and wants of target markets and delivering the desired satisfaction more efficiently and effectively than competitors. According to Drucker (1954), the purpose of every business is to create satisfied customers and clients.

The practical implementation of the marketing concept is referred to as market orientation. For many years, the subject of market orientation has occupied the center stage of the theory and practice of marketing strategy. Market orientation has been seen as a major factor that has an effect on organizational performance (Hoburg et al., 2003; Narver \& Slater, 1990), and as a valuable tool that influences firm innovativeness and performance by creating superior value to customers and clients (Narver \& Slater, 1990; Kotler, 1994; Shapiro, 1988; Webster, 1981; Kohli \& Jaworski, 1990, among others).

According to Sett (2017), relevant marketing literature sees market orientation as an operationalization of the marketing concept and as a source of sustainable competitive advantage (SCA) that may lead to superior firm performance. Kohli and Jaworski (1990) were the first to explain the domain of market orientation, and structured the market orientation construct into three organization-wide dimensional processes: information (or intelligence) generation, information (or intelligence) dissemination, and application of market intelligence. Also, Narver and Slater (1990) perceived market orientation as an organizational culture with three behavioral dimensions: customer orientation, competitor orientation, and inter-functional coordination. According to Deshpande and Farley (1998), the two conceptualizations of market orientation by Kohli and Jaworski (1990) and Narver and Slater (1990) are related. Therefore, subsequent elaborations by scholars and researchers have not altered the essence of the original market orientation construct as proposed by Kohli and Jaworski and Narver and Slater (Sett, 2017).

The cultural (Kohli \& Jaworski, 1990) and behavioural (Narver \& Slater, 1990) perspectives of market orientation have been differentiated in literature (Sommer, 2018). While the cultural perspective defines market orientation as an organizational mindset and culture, the behavioural perspective deals with organizational instruments, tools, and behaviours. It should be noted, however, that the cultural and behavioural conceptualizations of market orientation share many basic ideas in common (Noble, Sinha, \& Kumar, 2002) and are similar in the ways they have been operationalized (Cadogan \& Diamantopoulos, 1995). Therefore, researchers have combined both the cultural and behavioural perspectives of market orientation in many studies (Baumgarth, 2009; Brïdson \& Evans, 2004; Homburg \& Pflesser, 2000; Sommer, 2018).

Market orientation has been conceptualized by theorists and business decision-makers as the marketing concept in action (Gunnay, 2005).

Market orientation has also been conceptualized as a major part of capitalist economies (Matsuno et al., 2005), and as one of the management strategies leading to competitive advantage (Olson et al., 2005). Therefore, marketers in various industries and sectors (including service and manufacturing sectors) and cultures (including developed and developing countries) have been encouraged to adopt market orientation practices and strategies in their business decisions (Harris \& Ogbonna, 2001). Although some research efforts have been made to clarify relevant issues pertaining to the theory and practice of market orientation in developed and developing economies (Kohli \& Jaworski, 1990; Narvar \& Slater, 1990, among others), Harris and Ogbonna (2001) have argued that further research is needed in order to understand and clarify the market orientation construct in different contexts. According to Tomaskov (2007), market orientation can be defined as means which enable managers to emphasize external and internal issues influencing organizational activities and leading to performance improvements. Carpenter (2017) argues that market orientation, though an appealing concept, is less favoured and practised than other management approaches.

Chelariu et al. (2002) have advised, with regard to Sub-Saharan African countries, for the designing of market 
orientation research instruments which will measure the unique characteristics, practices and strategies of companies in different sectors. In this regard, some research efforts have been made with respect to the market orientation strategies of some organizations in Sub-Saharan Africa (Chelariu et al., 2002; Okoroafo, 2004; Osuagwu, 2006; Mbah et al., 2007, among others).

Bruhn and Hesselroth (2018) have observed that since the 1960s, it has been argued that customer and client needs should be main objective of every business organizations, concluding that one of the strategies to achieve this is via market orientation strategy. The market orientation emphases of firms can be industry-specific (Kasper, 2002). This means that some similarities may exist across all firms in an industry (Lado et al., 1998). However, cultural differences exist among firms in a sector and these cultural differences can lead to differences in their market orientation emphases (Kasper, 2002).

\section{Components of Market Orientation}

Market orientation has been conceptualized by scholars with regard to its components or dimensions. For example, Narver and Slater (1990) and Kohli et al. (1993) have isolated three components in their different conceptualizations of the market orientation construct. Also, Deng and Dart (1994) have identified four components of market orientation, while Lado et al. (1998) present eight components and Sorensen (2005) argue for two components. In addition, Filatochev et al. (2016) have argued that the market orientation construct has three subcomponents, namely customer orientation (which deals with understanding customers' and clients' needs and wants), competitor orientation (which is concerned with understanding competitors' strengths and weaknesses and how they satisfy clients' and customers' needs and wants), and inter-functional coordination (which is concerned with the organization-wide use of resources in creating superior customer and client satisfaction).

Generally, the market orientation construct has been conceptualized as a multi-dimensional construct (Edwards, 2001; Stoelhorst \& vanRaaij, 2004; Sett, 2017). For instance, Kohli and Jaworski (1990) have presented three major process components of the market orientation construct: generation of market information; dissemination of market information; and application of market information. Also, Narver and Slater (1990) presented three behavioural components of the market orientation construct: customer orientation; competitor orientation; and inter-functional coordination. The components of market orientation presented by Kohli and Jaworski (1990) and Narver and Slater (1990) are all compatible or related (Sett, 2017). According to Jaworski and Kohli (1993), market orientation has three major dimensions or components: market intelligence generation; dissemination of market-oriented intelligence or information; and facilitation of market intelligence responsiveness mechanism or system in the organization. Mavondo and Farrell (2000) have advised researchers investigating market orientation to choose the Narver and Slater's (1990) Market orientation construct instead of the Kohli and Jaworski (1990) market orientation because the Narver and Slater's (1990) market orientation construct is likely to provide consistent results.

Generally, market orientation has been conceptualized as a multi-dimensional construct that can affect organizational performance (Edwards, 2001; Stoelhorst \& vanRaaij, 2004; Sett, 2017). However, Liao et al. (2011) have argued for the need for researchers to determine, via empirical research, new dimensions of the market orientation construct. Sett (2017) argues that market orientation comprises three major dimensions, including sensing opportunities and threats; seizing opportunities and/or guarding against threats; and reconfiguring firm resources to align with environmental variations or changes. Also, Kumar et al. (2011) posit that there is need for researchers to discover new components or dimensions of the market orientation construct.

Generally, market orientation consists of: (1) customer orientation, (2) competitor orientation, (3) Inter-functional coordination, (4) sensitivity to the environment, (5) market information system to develop a greater understanding of these market orientation components, and (6) and achievement of effectiveness measures (Kohli \& Jaworski, 1990; Jaworski \& Kohli, 1993; Kumar et al., 2011; Narvar \& Slater, 1990; Slater \& Narver, 1994, 1995; among others). It can, therefore, be stated that there is no conclusion in relevant literature regarding the components of the market orientation construct. According to Kumar et al. (2011), there is need for researchers to discover new components or dimensions of the market orientation construct. Some of the components or dimensions of market orientation from literature are discussed below.

\section{Marketing Performance}

The idea of marketing performance has been contentious in relevant literature due mainly to failure to reach consensus regarding its definition. Therefore, marketing literature is associated with many definitions of marketing performance. For instance, Kayabasi and Mtetwa (2016) define marketing performance as the ability 
of a firm to achieve its short-term goals. In addition, Reimer, Rutz and Pauwels (2014) argue that marketing performance deals with the ability of a firm to achieve long term marketing goals.

The concept of marketing performance has been conceptualized mainly from the following two broad perspectives:

i. Financial perspective in relation to marketing activities, which is a short-term perspective of marketing performance (Daukseviaiute, Valainis, \& Vilkaute, 2011; Kayabasi \& Mtetwa, 2016; Reimer, Rutz, \& Pauwels, 2014).

ii. Assessment of marketing practices and strategies in relation to their ability to satisfy customers' and clients' needs and wants, which is a long-term perspective of marketing performance (Frosen, Tikkanen, Jaakkola, \& Vassinen, 2013; Brooks \& Simkin, 2012).

Although Greyser (1980) has documented the concerns of marketing decision-makers regarding how to measure the performance of firms' marketing decisions, there is the need for firms to assess the performance of their marketing decisions or practices. According to Kotler (1977), marketing performance is a multidimensional concept that may be measured through many indices. The indices are, generally, what a firm uses to determine whether its marketing practices and strategies have achieved the intended purposes (Forsen, Tikkanen, Jaakkola, \& Vassinen, 2013). Also, the indices of marketing performance can be quantitative ((Kayabasi \& Mtetwa, 2016) or qualitative (Srinivasan, Vanhuele, \& Pauwels, 2010). Marketing performance can be assessed using many indicators such as market share, sales volume and profitability, among others (Kotler, 1977; Narver \& Slater, 1990).

Therefore, it can be stated that there are components or dimensions of market orientation which an organization can practice in order to achieve its organizational goals (or performance measures). These market orientation components or dimensions, according to relevant literature, include customer satisfaction focus, coordination of inter-functional marketing activities, sensitivity to relevant marketing information, sensitivity to marketing environment and focus on marketing effectiveness, among others. Dimensions of performance measures include profit, market share, sales volume, cost reduction, employee satisfaction and customer satisfaction, among others.

\section{Market Orientation and Performance Relationships}

Management decisions are the major determinants of business success or failure (Barret \& Weinsten, 1998). Market orientation is an important management decision that can determine business performance (Jaworski \& Kohli, 1993), and it has been noted that there is a positive relationship between market orientation and business performance (Narver \& Slater, 1990).

Market orientation has been seen as a driver of business performance (Walsh \& Lipinski, 2009). It is the organizational culture which puts emphases on organizational client and customer and is the strategic resource that can improve organizational performance. It is an index of the degree to which an organization implements its marketing strategy, thereby enabling the company's ability to anticipate, react to and leverage on environmental dynamics in order to achieve its stated performance measures (Veira, 2010). Roomi et al. (2009) argue that the reason for an organization to adopt the market orientation construct is because of the construct's ability to link positively with some measures of performance. Chakravarthy (1986) argues that if this purpose is not achieved, there is no major reason for adopting market orientation in an organization. According to Fitatotchev et al. (2016), market orientation does not automatically improve organizational performance without appropriate supporting or mediating processes, concluding that just assessing the direct impact of market orientation on business performance without determining the mediators between market orientation and performance is not fruitful.

Relevant market orientation literature has reported a positive relationship between the degree of a company's market orientation emphases and its performance measures (Kirca, Jayachandran, \& Bearden, 2005). Specifically, Narver and Slater (1990) used only perceptual measures of performance to establish positive relationship between market orientation and measures of performance. However, Jaworski and Kohli (1993), using both perceptual and objective measures of performance, found no significant relationship between market orientation and market share, which is an objective measure of performance. Bhattarai, Kwonga and Tasavori (2019) submit that market orientation has been regarded in commercial business literature as an invaluable resource that can improve the performance of commercial business organizations, and conclude, using empirical evidence, that market orientation can improve both social performance and economic performance.

Deshpande and Farley (1998) have questioned why market orientation is not always strongly positively related 
with performance measures, speculating that the relationship between market orientation and measures of performance could be context-specific (i.e., with regard to national differences, economic development differences, or industry-specific issues, among others). Therefore, there are more important areas that need further research regarding the relationship between the market orientation construct and measures of performance (Deshpande \& Farley, 1998).

Relevant studies pertaining to the relationship between market orientation and performance measures may be grouped into two classes (Sett, 2017). The first group of studies, concerned with a direct link between market orientation and performance measures, are cross-sectional in nature, and used some moderating and mediating variables or none at all. The studies in this category, generally, suggest that the impacts of market orientation on performance measures are weaker on objective performance measures as compared to subjective (or perceptual) measures of performance. In related studies, Liao et al. (2011) found no clear empirical relationship between market orientation and objective measures of performance. Also, Cano et al. (2004) have found weak empirical relationships between market orientation and objective performance measures. In addition, Kirca et al. (2005) reported positive impact of market orientation on performance measures, although the study reported weak correlations between market orientation and objective measures of performance.

Sett (2017) posits that some relevant longitudinal studies have also reported weak relationships between the market orientation construct and objective measures of performance. For instance, the research by Noble et al. (2002) reported that only competitor orientation dimension of the Narver and Slater's (1990) operationalized market orientation construct showed any appreciable impact on objective measures of performance. Alsheq and Hossain (2019) argue, with empirical evidence, that market orientation has positive impact on the performance of small and medium enterprises.

Another group of studies on the relationships between market orientation and measures of performance matched market orientation with some intervening (mediating and/or moderating) variables. For instance, research by Hult and Ketchen (2001) reported that positive organization performance depends on market orientation, entrepreneurship orientation, innovativeness and organizational learning. Also, research by Hult et al. (2005) reported that the impact of market orientation on performance is mediated by organizational responsiveness, while research by Menguc and Auh (2006) found that the impact of market orientation on performance is more positive when market orientation is combined with innovativeness.

Therefore, conclusions from empirical studies dealing with the links between market orientation and marketing performance are equivocal. For instance, some studies have reported positive and significant relationships between the market orientation construct and business performance (Cano et al., 2004; Noble et al., 2002; Kumar et al., 2011; Kirca et al., 2005, among others). However, some studies have reported non-positive links between the market orientation construct and business performance (Jaworski \& Kohli, 1993; among others). According to Sett (2017), the impacts of market orientation on organizational performance have been investigated extensively, with empirical findings and evidence from corporate organizations not being conclusive. These equivocal empirical findings, therefore, seem to warrant the need for further research regarding the impacts of the market orientation construct on business performance (Shehu \& Mahmood, 2014).

Narver and Slater (1990) assert that a business that increases its market orientation will improve its market performance. This view has been supported by both marketing academics and managers for many years (Kotler, 1998; Webster, 1994; among others). According to Narver and Slater (1990), market orientation is the organizational culture that creates efficiency and effectiveness. Prifti and Alimehmeti (2017) posit that relevant literature has noted the positive impact of market orientation on business performance (Jaworski \& Kohli, 1993; Kumar et al., 1998; Boekema et al., 2000; Kanagasabai, 2008, Neil et al., 2009; Frösén et al., 2016, among others), particularly when subjective or judgmental measures of performance are used (Jaworski \& Kohli, 1993).

In summary, it can be stated that many studies have documented positive relationship between the market orientation construct and measures of business performance with or without mediating/moderating variables (Jaworski \& Kohli, 1996; Kumar, 2002; Narver \& Slater, 1990; Pelham \& Wilson, 1994, among others). Specifically, Hart and Diamantopoulos (1993) reported a positive relationship between market orientation and business performance and recommended the adoption of market orientation in organizations as an important aspect of business strategy. Therefore, it can be stated that the impact of market orientation on performance measures has not been settled in the market orientation literature. For instance, Dobni and Luffman (2003) and Stoelhorst and van Raaij (2004) submit that the approach to explain the impact of market orientation on performance has not been developed satisfactorily and that existing market orientation literature does not have an integrating framework that will combine the different dimensions of the market orientation construct to explain 
performance. In addition, Fitatotchev et al. (2016) argue that market orientation does not automatically improve organizational performance without appropriate supporting or mediating processes, concluding that just assessing the direct impact of market orientation on business performance without determining the mediators between market orientation and performance is not fruitful.

Also, although market orientation has been seen to create superior performance in western economies, the implementation still leaves some gaps in developing countries (Gunnay, 2005). In addition, studies on market orientation and its relationship to organizational performance in the service industry in a developing country context have been scarce. As mentioned previously, market orientation has been seen to be an important strategic tool in western economies. However, its understanding and application in developing economies have not been fully understood and explored. In addition, studies related to market orientation and its relationship to organizational performance in the service industry has been scarce. Against this backdrop, it is suggested that future studies be undertaken to determine the emphases, dimensions and performance-impacts of market orientation in different contexts, especially in different business sectors (service/manufacturing, profit/non-profit organizations) in countries in sub-Saharan Africa.

This paper has developed, from relevant literature, a conceptual framework linking market orientation dimensions and performance indices with or without any mediating/moderating constructs or variables. Therefore, based on the literature review regarding components of market orientation and relationships between market orientation and performance measures, the conceptual framework shown in Figure 1 below has been generated for the understanding of some market orientation issues and assist future research efforts.

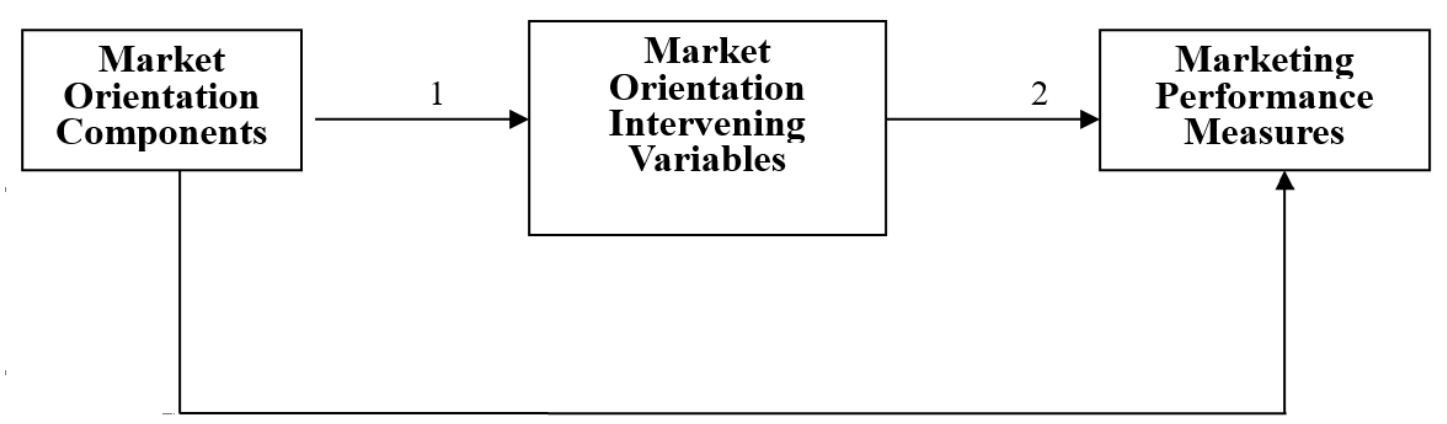

Figure 1. Market Orientation/Performance Relationships Framework developed from Literature (with or without intervening (mediating/moderating) variables

The conceptual framework in Figure 1 shows the relationships among three major constructs: Market Orientation Components, Market Orientation Intervening Variables and Marketing Performance Measures. These three major constructs can be operationalized as follows: Market orientation components comprise customer orientation, competitor orientation, inter-functional coordination, environmental orientation, and marketing information, among others. Market orientation intervening variables (mediating or moderating) comprise entrepreneurship orientation, innovativeness, organizational learning, and organizational responsiveness, among others. Marketing performance measures comprise profit, market share, sales volume, cost reduction, employee satisfaction and customer satisfaction, among others. These three major constructs are interconnected in some instances (Osuagwu, 2016).

\section{Conclusion and Suggestions for Further Research}

Market orientation is an important strategy for organizational effectiveness and efficiency. However, the conceptualizations, components and performance-impacts of market orientation have not been settled in the literature. Consequently, the following areas are suggested for further studies in order to have a better and enhanced understanding of the market orientation construct and practice in organizations:

i Objective measures of performance should be used in market orientation studies to overcome the issues associated with the use of perceptual measures of performance. Specifically, self-reported or perceptual measures of performance tend to be biased. 
ii Further research should be undertaken to determine how certain factors (such as innovativeness and entrepreneurship, among others) moderate or mediate the performance impacts of market orientation in companies. According to Fitatotchev et al. (2016), market orientation does not automatically improve organizational performance without appropriate supporting or mediating processes, concluding that just assessing the direct impact of market orientation on business performance without determining the mediators between market orientation and performance may not be fruitful.

iii In addition, it is suggested that further research be undertaken to investigate the emphases, components and performance impacts of market orientation in different contexts (such as sectors, time periods, profit/non-profit organizations, among others). Such studies are likely to provide robust and clearer knowledge of the market orientation construct with regard to its conceptualizations, components and performance-impacts.

iv It is suggested that the conceptual framework developed in this paper be tested in different contexts to determine its fit to real-world data and provide more insights to the market orientation construct (Harris \& Ogbonna, 2001).

$\mathrm{v}$ The literature review revealed the limitations (for instance, claims of causality) associated with the use of cross-sectional data in market orientation research. Therefore, longitudinal approach to investigating market orientation issues is suggested for future studies.

vi Countries differ with regard to national and economic development issues. Therefore, further research is suggested to explore differences between specific developed and developing countries with regard to relevant market orientation issues of research interest.

vii Finally, it is suggested that future studies be undertaken by using qualitative research approaches. This line of suggestion is supported by Schein (1996) who has argued that some organizational cultural practices, such as market orientation, cannot be accurately evaluated via survey instruments of quantitative research. Therefore, qualitative research approaches, such as individual in-depth interviews and focus group discussions, among others, should be considered as likely research approaches to be used in future market orientation studies.

\section{References}

Alsheq, A., \& Hossain, M. U. (2019). SME Performance: Impact of Market, Customer and Brand Orientations. Academy of Marketing Studies Journal, 23(1), 1-10.

Amalia, P., Ionu, P., \& Cristian, N. (2008). Market Orientation: An Interdisciplinary and Complex Concept. The Journal of the Faculty of Economics, 1055-1059.

Awwad, M. S., \& Agti, D. A. M. (2011). The Impact of Internal Marketing on Commercial Banks' Market Orientation. International Journal of Bank Marketing, 29(4), 308-332. https://doi.org/10.1108/02652321111145943

Babatunde, B. O., \& Adebisi, A. O. (2012). Strategic Environmental Scanning and Organization Performance in a Competitive Business Environment. Economic Insights - Trends and Challenges, 64(1), 24-34.

Barett, H., \& Weinsten, A. (1998). The Effect of Market Orientation and Organizational Flexibility on Corporate Performance. Entrepreneurship: Theory and Practice, 23(1), 57-68. https://doi.org/10.1177/104225879802300103

Baumgarth, C. (2009). Brand Orientation of Museums: Model and Empirical Results. International Journal of Arts Management, 11(3), 30-45.

Bharadwaj, N., \& Matsuno, K. (2006). Investigating the Antecedents and Outcomes of Customer Firm Transaction Cost Saving in a Supply Chain Relationship. Journal of Business Research, 59, 62-72. https://doi.org/10.1016/j.jbusres.2005.03.007

Bhattarai, C. J., Kwonga, C. C. Y., \& Tasavori, M. (2019). Market Orientation, MarketlDisruptiveness Capability and Social Enterprise Performance: An Empirical Study from the United Kingdom. Journal of Business Research, 96, 47-60. https://doi.org/10.1016/j.jbusres.2018.10.042

Bjornseth, I., \& Szabo, A. (2018). Sexual Violence Against Children in Sports and Exercise: A Systematic Literature Review. Journal of Child Sexual Abuse, 27(4), 365-385. https://doi.org/10.1080/10538712.2018.1477222

Boekema, F., Morgan, K., Bakkers, S., \& Rutten, R. (2000). Knowledge, Innovation and Economic Growth. Cheltenham: Edward Elgar Publishing.

Borenstein, M., Hedges, L. V, Higgins, J. P. T., \& Rothstein, H. R. (2011). Introduction to Meta-Analysis, Sussex: Wiley \& Sons. 
Brïdson, K., \& Evans, J. (2004). The Secret to a Fashion Advantage is Brand Orientation. International Journal of Retail \& Distribution Management, 32(8), 403-411. https://doi.org/10.1108/09590550410546223

Brooks, N., \& Simkin, L. (2012). Judging Marketing Mix Effectiveness. Marketing Intelligence \& Planning, 30(5), 494-514. https://doi.org/10.1108/02634501211251025

Bruhn, A., \& Hesselroth, M. (2018). Market Orientation: The Effect of TMT Shared Leadership and Perceived Contextual Discretion. MBA Thesis, School of Health \& Society.

Cadogan, J. W., \& Diamantopoulos, A. (1995). Narver and Slater, Kohli and Jaworski and the Market Orientation Construct: Integration and Internationalization. Journal of Strategic Marketing, 3(1), 41-60. https://doi.org/10.1080/09652549500000003

Cano, C. R., Carrillat, F. A., \& Jaramillo, F. (2004). A Meta-Analysis of the Relationship between Market Orientation and Business Performance: Evidence from Five Continents. International Journal of Research in Marketing, 21, 179-200. https://doi.org/10.1016/j.ijresmar.2003.07.001

Carpenter, J. M., \& Fairhurst, A. (2005). Consumer Shopping Satisfaction, and loyalty for Retail Apparel Brands. Journal of Fashion Marketing and Management, 3(9), 256-269. https://doi.org/10.1108/13612020510610408

Chakravarthy, B. S. (1986). Measuring Strategic Performance. Strategic Management Journal, 7, 437-458. https://doi.org/10.1002/smj.4250070505

Chelariu, C., Ouattarra, A., \& Dadzie, K. Q. (2002). Market Orientation in Ivory Coast: Measurement Validity and Organizational Antecedents in a Sub-Saharan Africa Economy. Journal of Business \& Industrial Marketing ${ }_{2}$ 17(6), 456-470. https://doi.org/10.1108/08858620210442811

Daukseviciute, I., Valainis, A., \& Vilkaite, N. (2011). Conceptualization of Effectiveness of Marketing Tools. Intellectual Economics Research Journal, 5(2), 200-211.

Deng, S., \& Dart, J. (1994). Measuring Market Orientation: A Multifactor, Multi-item Approach. Journal of Marketing Management, 10(8), 725-742. https://doi.org/10.1080/0267257X.1994.9964318

Deshpande, R., Farley, J. U., \& Webster, F. E. (1989). Organizational Culture and Marketing: Defining the Research Agenda. Journal of Marketing, 53, 3-15. https://doi.org/10.1177/002224298905300102

Deshpande, R., Farley, J. U., \& Webster, F. E. (1994). Corporate Culture Customer Orientation and Innovativeness in Japanese Firms: A Quardred Analysis. Journal of marketing, 57, 23-27. https://doi.org/10.1177/002224299305700102

Deshpande, R., \& Farley, J. U. (1998). Measuring Market Orientation: Generalization and Synthesis. Journal of Market-Focused Management, 2, 213-232. https://doi.org/10.1023/A:1009719615327

Deshpande, R., \& Farley, J. U. (1998a). The Market Orientation Construct: Correlations, Culture and Comprehensiveness. Journal of Market Focused Management, 2, 237-239. https://doi.org/10.1023/A:1009751600306

Dobni, C. B., \& Luffman, G. (2003). Determining the Scope and Impact of Market Orientation Profiles on Strategy Implementation and Performance. Strategic Management Journal, 24, 577-585. https://doi.org/10.1002/smj.322

Drucker, P. F. (1954). The Practice of Management. New York: Harper \& Row

Dursun-Kilic, T. (2006). An Empirical Investigation of the Link between Market Orientation and New Product Performance: The Mediating Effects of Organizational capabilities. Norfolk, Virginia: Old Dominion University ( $\mathrm{PhD}$ thesis).

Easterby-Smith, M., Thorpe, R., \& Jackson, P. (2015). Management \& Business Research (5th ed.). London: Sage Publications.

Edwards, J. R. (2001). Multidimensional constructs in organizational behavior research: An integrative analytical framework. Organizational Research Methods, 4, 144-192. https://doi.org/10.1177/109442810142004

Filatotchev, I., Su, Z., \& Bruton, G. D. (2016). Market Orientation, Growth Strategy and Firm Performance: The Moderating Effects of External Connections. Management and Organizational Review, 3, 1-27. https://doi.org/10.1017/mor.2016.31 
Frosen, J., Tikkanen, H., Jaakkola, M., \& Vassinen, A. (2013). Marketing Performance Assessment Systems and Business Context. European Journal of Marketing, 47(5/6), 715-737. https://doi.org/10.1108/03090561311306688

Frösén, J., Luoma, J., Jaakkola, M., Tel, U. K., Tikkanen, H., Aspara, J., \& Laukkanen, M. (2016). What Counts versus What Can be Counted: The Complex Interplay of Market Orientation and Marketing Performance Measurement in Organizational Configurations. Journal of Marketing, 80(3), 1-16. https://doi.org/10.1509/jm.15.0153

Gunnay, G. N. (2005). Market Orientation and Globalization Among the Turkish Clothing Exporter. In E. Kaynak \& F. D. Sarvan (Eds.), The Impact of Globalization on World Business: Competition, Cooperation, Environment, and Development (pp. 753-759). Proceedings of the IMDA 11th World Business congress, Turkey.

Greyser, S. A. (1980). Marketing Issues. Journal of Marketing, 44, 89-92. https://doi.org/10.1177/002224298004400112

Grinstein, A. (2008). The Relationships between Market Orientation and Alternative Strategic Orientations: A Meta-Analysis. European Journal of Marketing, 42(1/2), 115-134. https://doi.org/10.1108/03090560810840934

Han, J. K., Kim, N., \& Srivastava, R. K. (1998). Market Orientation and Organizational Performance: Is Innovation a Missing Link? Journal of Marketing, 62(4), 30-45. https://doi.org/10.2307/1252285

Harris, L. C., \& Ogbonna, E. (2001). Leadership Style and Market Orientation: An Empirical Study. European Journal of Marketing, 35(5/6), 744-764. https://doi.org/10.1108/03090560110388196

Harris, L. C., \& Ogbonna, E. (2006). Initiating Strategic Planning. Journal of Business Research, 59, 100-111. https://doi.org/10.1016/j.jbusres.2005.02.003

Hart, S., \& Diamantopoulos, A. (1993). Linking Market Orientation and Company Performance: Preliminary Work on Kohli and Jaworski's Framework. Journal of Strategic Marketing, 1(2), 93-122. https://doi.org/10.1080/09652549300000007

Helfat, C. E., \& Peteraf, M. A. (2003). The dynamic Resource-based View: Capability Lifecycle. Strategic Management Journal, 24(10), 997-1010. https://doi.org/10.1002/smj.332

Higgins, J. A., \& Smith, N. K. (2016). The Sexual Acceptability of Contraception: Reviewing the Literature and Building a New Concept. The Journal of Sex Research, 53(4/5), 417-456. https://doi.org/10.1080/00224499.2015.1134425

Hodgkinson, G., \& Johnson, G, (1994). Exploring the Mental Models of Competitive Strategies: The Case for Processual Approach. Journal of Management Studies, 3(4), 525-551. https://doi.org/10.1111/j.1467-6486.1994.tb00629.x

Homburg, C., \& Pflesser, C. (2000). A Multiple-layer Model of Market-Oriented Organizational Culture: Measurement Issues and Performance Outcomes. Journal of Marketing Research, 37(4), 449-462. https://doi.org/10.1509/jmkr.37.4.449.18786

Hooley, G. J., Greenley, G. E., Cadogan, J. W., \& Fahy, J. (2005). The Performance Impact of Marketing Resources. Journal of Business Research, 58(1), 18-27. https://doi.org/10.1016/S0148-2963(03)00109-7

Hult, T. G., \& Ketchen, D. J. (2001). Does Market Orientation Matter? A Test of the Relationship between Positional Advantage and Performance. Strategic Management Journal, 22, 899-906. https://doi.org/10.1002/smj.197

Hult, T. G., Ketchen, D. J., \& Slater, S. F. (2005). Market Orientation and Performance: An Integration of Disparate Approaches. Strategic Management Journal, 22, 1173-1181. https://doi.org/10.1002/smj.494

Jabeen, R., Alekam, J. M. E., Aldaoud, K. A. M., Mat, N. K. N., Zureigat, B. N. I., \& Nahi, A. K. (2013). Antecedents of Firm's Performance: Empirical Evidence from Yemeni SMEs. American Journal of Economics, 3(1), 18-22.

Jaworski, B. J., \& Kohli, A. K. (1993). Market Orientation: Antecedents and Consequences. Journal of Marketing, 57, 34-42. https://doi.org/10.1177/002224299305700304

Jaworski, B. J., \& Kohli, A. K. (1996). Market Orientation: Review, Refinement and Roadmap. Journal of Market-focused Management, 1, 119-125. https://doi.org/10.1007/BF00128686 
Kasper, H. (2002). Culture and Leadership in Market-Oriented Service Organizations. European Journal of Marketing, 36(9/10), 1047-1057. https://doi.org/10.1108/03090560210437325

Kayabasi, A., \& Mtetwa, T. (2016). Impact of Marketing Effectiveness and Capabilities and Export Market Orientation on Export Performance: Evidence from Turkey. European Business Review, 28(6), 532-559. https://doi.org/10.1108/EBR-11-2014-0084

Kirca, A. H., Jayachandran, S., \& Bearden, W. O. (2005). Market Orientation: A Meta-Analytic Review and Assessment of its Antecedents and Impact on Performance. Journal of Marketing, 69, 24-41. https://doi.org/10.1509/jmkg.69.2.24.60761

Kohli, A. K., \& Jaworski, B. (1990). Market Orientation: The Construct, Research Propositions and Managerial Implications. Journal of Marketing, 54, 1-15. https://doi.org/10.2307/1251866

Kohli, K., Jaworski, B. J., \& Kumar, A. (1993). MARKOR: Measure of Market Orientation. Journal of Marketing Research, 30(4), 467-478. https://doi.org/10.2307/3172691

Kotler, P. (1977). From Sales Obsession to Marketing Effectiveness. Harvard Business Review, 55, 67-75.

Kotler, P. (1998). Marketing Management (11th ed.). Upper Saddle River. New Jersey: Pearson Education, Inc.

Kotler, P., \& Armstrong, G. (2008). Principles of Marketing (12th ed.). Upper Saddle River, New Jersey: Pearson Education, Inc.

Kotler, P., \& Keller, K. (2007). Marketing Management (12th ed.). New Delhi: Prentice-hall Inc.

Kumar, K., Subramanian, R., \& Yauger, C. (1998). Examining the Market Orientation-Performance Relationship: A Context-Specific Study. Journal of Management, 24(2), 201-233. https://doi.org/10.1177/014920639802400204

Kumar, K. (2002). Market Orientation, Organizational Competencies and Performance: An Empirical Investigation of a Path-Analytic Model. Journal of American Academy of Business, 1(2), 371-376.

Kumar, V., Jones, E., Venkatesan, R., \& Leone, R. P. (2011). Is Market Orientation a Source of Sustainable Competitive Advantage or Simply the Cost of Competing? Journal of Marketing, 75(1), 16-30. https://doi.org/10.1509/jm.75.1.16

Lado, N., Maydeu-Olivares, A., \& Rivera, J. (1998). Measuring Market Orientation in Several Populations: A Structural Equation Model. European Journal of Marketing, 32(1/2), 23-39. https://doi.org/10.1108/03090569810197408

Levitt, T. (1980). Marketing Myopia. Harvard Business Review, 38(4), 45-56.

Liao, S. H., Chang, W. J., Wu, C. C., \& Katrichis, J. M. (2011). A Survey of Market Orientation Research (1995-2008). Industrial Marketing Management, $40,321$. https://doi.org/10.1016/j.indmarman.2010.09.003

Luo, X., Sivakumer, K., \& Liu, S. S. (2005). Globalization, Marketing Resources, and Performance: Evidence from China. Journal of the Academy of Marketing Science, 33(1), 50-65. https://doi.org/10.1177/0092070304265050

Matsuno, K., Mentzer, J. T., \& Rentz, J. O. (2005). A Conceptual and Empirical Comparison of Three Market Orientation Scales. Journal of Business Research, 58(1), 1-8. https://doi.org/10.1016/S0148-2963(03)00075-4

Matt, G. E., \& Cook, T. D. (1994). Threats to the Validity of Research Syntheses. In H. Cooper \& L. V. Hedges (Eds.), Handbook of Research Synthesis (pp. 503-520). New York: Russell Sage Publications.

Mavondo, F. T., \& Farrell, M. A. (2000). Measuring Market Orientation: Are There Difference Between Business Marketers and Consumer Marketers. Australian Journal of Management, 25(2) 223-244. https://doi.org/10.1177/031289620002500206

Mbah, C., Ogbuehi, A., \& Blankson, C. (2007). The Challenges of Market Orientation Strategies Implementation in an Emerging Economy. Journal of Business Case Studies, 3(2), 34-52. https://doi.org/10.19030/jbcs.v3i2.4840

Meij, M. G. V., Broerse, J. E. W., \& Kupper, F. (2017). Conceptualizing Playfulness for Reflection Processes in Responsible Research \& Innovation Contexts: A Narrative Literature Review. Journal of Responsible Innovation, 4(1), 43-63. https://doi.org/10.1080/23299460.2017.1326258 
Menguc, B., \& Auh, S. (2006). Creating Firm level Dynamic Capability Through Capitalizing on Market Orientation and Innovativeness. Journal of Academy of Marketing Research, 34(1), 61-73. https://doi.org/10.1177/0092070305281090

Narver, J. C., \& Slater, S. F. (1990). The Effects of Market Orientation on Business Profitability. Journal of Marketing, 54, 20-35. https://doi.org/10.1177/002224299005400403

Nasheeda, A., Abdullah, H. B., Krauss, S. E., \& Ahmed, N. B. (2018). A Narrative Systematic Review of Life Skills Education: Effectiveness, Research Gaps and Priorities. International Journal of Adolescence and Youth. https://doi.org/10.1080/02673843.2018.1479278

Noble, C. H., Sinha, R. K., \& Kumar, A. (2002). Market Orientation and Alternative Strategic Orientations: A Longitudinal Assessment of Performance Implications. Journal of Marketing, 66(4), 25-39. https://doi.org/10.1509/jmkg.66.4.25.18513

Okoroafo, S. C. (2004). Marketing Orientation, Practices, and Performance of Sub-Saharan African Firms: A Review. Journal of African Business, 5(2), 163-172. https://doi.org/10.1300/J156v05n02_09

Olson, E. M., Slater, S. F., \& Hult, G. T. M. (2005). The Importance of Structure and Process to Strategy Implementation. Business Horizon, 48(1), 47-54. https://doi.org/10.1016/j.bushor.2004.10.002

Osuagwu, L. (2006). Market Orientation in Nigerian Companies. Marketing Intelligence \& Planning, 24(6), 608-631. https://doi.org/10.1108/02634500610701681

Osuagwu, L. (2016). A Model of Strategic Marketing Decision Premises. International Journal of Marketing Studies, 8(3), 145-153. https://doi.org/10.5539/ijms.v8n3p145

Pelham, A. M., \& Wilson. D. T. (1996). A Longitudinal Study of the Impact of Market Structure, Firm Structure, Strategy and Market Orientation Culture on Dimensions of Small-Firm Performance. Journal of the Academy of Marketing Science, 24(1), 27-43. https://doi.org/10.1007/BF02893935

Powpaka, S. (2006). How Market Orientation Affects Female Service Employees in Thailand. Journal of Business Research, 59, 54-61. https://doi.org/10.1016/j.jbusres.2005.03.004

Priem, R. L., \& Butler, J. E. (2001). Is the Resource-based View a Useful Perspective for Strategic Management Research? The Academy of Management Review, 26(1), 22-40. https://doi.org/10.5465/amr.2001.4011928

Prifti, R., \& Alimehmeti, G. (2017). Market Orientation, Innovation and Firm Performance: An Analysis of Albanian Firms. Journal of Innovation \& Entrepreneurship, 6(8), 1-19. https://doi.org/10.1186/s13731-017-0069-9

Reimer, K., Rutz, O. J., \& Pauwels, K. (2014). How Online Consumer Segments Differ in Long-Term Marketing $\begin{array}{llll}\text { Effectiveness. Journal of Interactive } & \text { Marketing, 28(4), 284. }\end{array}$ https://doi.org/10.1016/j.intmar.2014.05.002

Ries, A., \& Trout, J. (1986). Marketing Warfare. New York: McGraw-Hill, Inc. https://doi.org/10.1108/eb008182

Roomi, M. A., Harrison, P., \& Beaumont-Kerridge, J. (2009). Women-owned Small and Medium Enterprises in England: Analysis of Factors Influencing the Growth Process. Journal of Small Business and Enterprise Development, 16(2), 270-288. https://doi.org/10.1108/14626000910956056

Schein, E. H. (1996). Culture: The Missing Concept in Organizational Studies. Administrative Science Quarterly, 41, 229-240. https://doi.org/10.2307/2393715

Sett, R. K. (2017). Market Orientation-Firm Performance Link in a Dynamic Environment: Looking inside the Black Box. Academy of Marketing Science Review, AMS Review (Online). https://doi.org/10.1007/s13162-017-0099-2

Shapiro, B. P. (1988). What the Hell is Market Oriented? Harvard Business Review, 34, 119-125.

Shehu, A. M., \& Mahmood, R. (2014). An Empirical Analysis of Market Orientation and Business Performance Relationship in the Context of Developing Economy. International Journal of Academic Research in Business \& Social Sciences, 4(9), 457-470. https://doi.org/10.6007/IJARBSS/v4-i9/1151

Sirelkhatim, F., \& Gangi, Y. (2015). Entrepreneurship Education: A Systematic Literature Review of Curricula Contents \& Teaching Methods. Cogent Business \& Management, 2, 1-11. https://doi.org/10.1080/23311975.2015.1052034

Smith, M. L., \& Glass, G. V. (1977). Meta-Analysis of Psychotherapy Outcome Studies. American Psychologist, 
32, 752-760. https://doi.org/10.1037/0003-066X.32.9.752

Sommer, C. (2018). Market Orientation of New Startups. The Journal of Media Innovations, 4(2),34-54.

Sorensen, E. (2005). On market Orientation. Management, 3, 23-31.

Srinivasan, S., Vanhuele, M., \& Pauwels, K. (2010). Mindset Metrics in Market Response Models: An Integrative Approach. Journal of Marketing Research, 47(4), 672-684. https://doi.org/10.1509/jmkr.47.4.672

Stoelhorst, J. W., \& van Raaij, E. M. (2004). On Explaining Performance Differentials: Marketing and the Managerial Theory of the Firm. Journal of Business Research, 57(5), 462-477. https://doi.org/10.1016/S0148-2963(02)00313-2

Thorpe, R., Holt, R., Pittaway, L., \& Macpherson, A. (2006). Knowledge within Small and Medium-Sized Firms: A Systematic Review of the Evidence. International Journal of Management Reviews, 7, 257-281. https://doi.org/10.1111/j.1468-2370.2005.00116.x

Tomaskova, E. (2007). The Current Models of Market Orientation. European Research Studies, XI, Special Issue (3-4), 1-8.

Toracco, R. J. (2005). Writing Integrative Literature Review: Guidelines and Examples. Human Resource Development Review, 4(3), 356-367. https://doi.org/10.1177/1534484305278283

Vieira V. A. (2010). Antecedents and Consequences of Market Orientation: A Brazilian Meta-Analysis and an International Mega-Analysis. Brazilian Administration Review, 7, 44-58. https://doi.org/10.1590/S1807-76922010000100004

Walsh, F. M., \& Lipinski, J. (2009). The Role of the Marketing Function in Small and Medium Sized Enterprises. Journal of Small Business and Enterprise Development, 16, 569-585. https://doi.org/10.1108/14626000911000929

Webster, C. (1993). Refinement of the Marketing Core Scale and the Relationship Between Marketing Culture and Profitability of a Service Firm. Journal of Business Research, 26(2), 111-131. https://doi.org/10.1016/0148-2963(93)90001-6

Webster, F. (1994), Market-driven Management. New York, NY: John Wiley \& Sons Inc.

Wee, B. V., \& Banister, D. (2016). How to Write Literature Review Paper. Transport Review, 36(2), 278-288. https://doi.org/10.1080/01441647.2015.1065456

\section{Copyrights}

Copyright for this article is retained by the author, with first publication rights granted to the journal.

This is an open-access article distributed under the terms and conditions of the Creative Commons Attribution license (http://creativecommons.org/licenses/by/4.0/). 